\title{
Genetic Deletion of the Nociceptin/Orphanin FQ Receptor in the Rat Confers Resilience to the Development of Drug Addiction
}

\author{
Marsida Kallupi ${ }^{1,2,6}$, Giulia Scuppa ${ }^{1,6}$, Giordano de Guglielmo ${ }^{1,2}$, Girolamo Calò ${ }^{3}$, Friedbert Weiss ${ }^{4}$, \\ Michael A Statnick ${ }^{5}$, Linda M Rorick-Kehn ${ }^{\mathbf{5}}$ and Roberto Ciccocioppo*,I \\ 'School of Pharmacy, Pharmacology Unit, University of Camerino, Camerino, Italy; ${ }^{2}$ Committee on the Neurobiology of Addictive Disorders, \\ The Scripps Research Institute, La Jolla, CA, USA; ${ }^{3}$ Department of Medical Science, Section of Pharmacology and National Institute of Neuroscience, \\ University of Ferrara, Ferrara, Italy; ${ }^{4}$ Molecular and Cellular Neuroscience Department, The Scripps Research Institute, La Jolla, CA, USA; \\ ${ }^{5}$ Lilly Research Laboratories, Lilly Corporate Center, Indianapolis, IN USA
}

\begin{abstract}
The nociceptin (NOP) receptor is a G-protein-coupled receptor whose natural ligand is the NOP/orphanin FQ (N/OFQ) peptide. Evidence from pharmacological studies suggests that the N/OFQ system is implicated in the regulation of several addiction-related phenomena, such as drug intake, withdrawal, and relapse. Here, to further explore the role of NOP system in addiction, we used NOP $(-/-)$ rats to study the motivation for cocaine, heroin, and alcohol self-administration in the absence of N/OFQ function. Conditioned place preference (CPP) and saccharin $(0.2 \% \mathrm{w} / \mathrm{v})$ self-administration were also investigated. Results showed that NOP $(-/-)$ rats selfadminister less cocaine $(0.25,0.125$, or $0.5 \mathrm{mg} /$ infusion) both under a fixed ratio I and a progressive ratio schedule of reinforcement compared with wild-type (Wt) controls. Consistently, cocaine $(10 \mathrm{mg} / \mathrm{kg}$, i.p.) was able to induce CPP in Wt but not in NOP $(-/-)$. When NOP $(-/-)$ rats were tested for heroin $(20 \mu \mathrm{g} /$ infusion) and ethanol ( $10 \% \mathrm{v} / \mathrm{v})$ self-administration, they showed significantly lower drug intake compared with Wt. Conversely, saccharin self-administration was not affected by NOP deletion, excluding the possibility of nonspecific learning deficits or generalized disruption of reward mechanisms in NOP $(-/-)$ rats. These findings were confirmed with pharmacological experiments using two selective NOP antagonists, SB-6I2III and LY28/74I2. Both drugs attenuated alcohol selfadministration in Wt rats but not in NOP $(-/-)$ rats. In conclusion, our results demonstrate that genetic deletion of NOP receptors confers resilience to drug abuse and support a role for NOP receptor antagonism as a potential treatment option for drug addiction. Neuropsychopharmacology (2017) 42, 695-706; doi:I0.1038/npp.2016.171; published online 2I September 2016
\end{abstract}

\section{INTRODUCTION}

The nociceptin (NOP; or opioid-receptor-like) receptor is a G-protein-coupled receptor whose natural ligand is the neuropeptide NOP/orphanin FQ (N/OFQ; Meunier et al, 1995; Reinscheid et al, 1995).

Neuroanatomical and immunohistochemical studies have shown that N/OFQ and its receptor are widely distributed in brain areas involved in reward and motivation and have a determinant role in shaping drug abuse-related behaviors. High-to-moderate receptor expression has been reported in the central nucleus of the amygdala (CeA), the bed nucleus of stria terminalis (BNST), medial prefrontal cortex, ventral tegmental area (VTA), lateral hypothalamus, nucleus accumbens, and some brainstem areas, including the locus

\footnotetext{
* Correspondence: Professor R Ciccocioppo, School of Pharmacy, Pharmacology Unit, University of Camerino, Camenino, 62032 Italy, Tel: +39 073740 3313, Fax +3907 3740 3325, E-mail: roberto.ciccocioppo@unicam.t ${ }^{6}$ These authors contributed equally to this manuscript. Received 12 May 2016; revised 12 August 2016; accepted 13 August 2016; accepted article preview online 26 August 2016
}

coeruleus and dorsal raphe (Ciccocioppo et al, 2000a; Darland et al, 1998; Mollereau and Mouledous, 2000).

Consistent with this localization, evidence suggests that the N/OFQ system is involved in the regulation of several addiction-related phenomena, including drug intake, withdrawal, and relapse for a variety of psychotropic agents including opioids, psychostimulants, and ethanol (Ciccocioppo et al, 2000a; Kallupi et al, 2014; Witkin et al, 2014; Zaveri, 2011).

Genetic association studies in humans further support the notion of a link between the N/OFQ system and drug addiction. For example, Huang et al. (2008) have reported a single-nucleotide polymorphism (SNP rs6010718) in the gene encoding the NOP receptor in alcohol-dependent individuals. In other studies, genetic variants of the OPRL1 gene were associated with opioid dependence (Xuei et al, 2008; Briant et al, 2010). In addition, increased vulnerability to alcohol dependence has been recently linked to DNA hypermethylation of the promoter regions of several genes, including the one encoding the NOP receptor suggesting the possibility that alcohol abuse is associated with a 
repressed NOP gene transcription (Zhang et al, 2013). Altogether, these studies confirm the important role of the NOP system in modulating addictive behavior and also suggest that changes in NOP receptor expression may occur during the transition from an occasional drug intake to drug addiction.

Preclinical data showed that intracranial administration of N/OFQ was able to prevent the acquisition of conditioned place preference (CPP) induced by morphine (Ciccocioppo et al, 2000b; Sakoori and Murphy, 2008b). However, when other aspects of opioid addiction were investigated, some negative results were obtained. For example, N/OFQ failed to modify the development of morphine-induced locomotor sensitization (Ciccocioppo et $a l, 2000 \mathrm{~b}$ ) and did not alter heroin self-administration in rats (Walker et al, 1998).

It was also shown that N/OFQ prevents the expression of CPP engendered by psychostimulants such as cocaine or methamphetamine (Kotlinska et al, 2002; Zhao et al, 2003). Data were replicated following peripheral administration of brain penetrant synthetic agonists (Rutten et al, 2010).

Strongest evidence for a role of NOP agonism as an efficacious approach to treat drug addiction comes from studies carried out in alcohol-preferring marchigian sardinian $(\mathrm{msP})$ rats, an animal line genetically selected for high ethanol preference and excessive drinking (Ciccocioppo et al, 2006). In these rats, NOP agonists attenuate home cage alcohol drinking, operant alcohol self-administration, and drug seeking elicited by stress and environmental conditioning factors (Ciccocioppo et al, 2004; Economidou et al, 2006a, 2008). The efficacy of NOP agonists on alcohol intake has also been documented in post-dependent outbred Wistar rats whereas they are not effective in nondependent Wistar rats, unless very high doses are used (de Guglielmo et al, 2015a; Economidou et al, 2006a; Kuzmin et al, 2007).

Nevertheless, the assumption that activation of NOP receptors may have a therapeutic potential in addiction, is incompatible with other studies that we have recently published, in which we demonstrated that the msP rat line showed higher expression of N/OFQ and NOP receptor mRNA in numerous brain regions compared with their Wistar counterparts, accompanied by significantly increased NOP receptor binding within the CeA, BNST, VTA, and several cortical structures (Economidou et al, 2008). These observations are, in fact, indicative of an association between innate upregulation of the N/OFQ-NOP system and high ethanol preference in $\mathrm{msP}$ rats.

Most importantly, we have recently found that blockade of NOP receptors by selective antagonism, attenuates alcohol consumption, and seeking in genetically selected alcohol-preferring rats, rising the possibility that receptor blockade might be beneficial in alcoholism (Rorick-Kehn et al, 2016).

Recently, using a target-selected $N$-ethyl- $N$-nitrosourea (ENU)-driven mutagenesis, a new mutant rat line carrying a constitutive deletion of the NOP receptor due to the induction of a premature stop codon in the gene coding for the ORL-1 receptor transcript has been generated (Homberg et al, 2009). This new animal model has already been characterized behaviorally by Rizzi et al (2011) who found that, consistent with antidepressant properties of NOP antagonists, NOP-receptor knock-out NOP $(-/-)$ rats displayed resilience to depressive-like behaviors (Gavioli and Calo, 2013; Holanda et al, 2016; Rizzi et al, 2011; Witkin et al, 2014). On the other hand, in agreement with the anxiolyticlike effects of NOP agonists, NOP $(-/-)$ rats expressed a mild anxious-like phenotype (Jenck et al, 2000; Rizzi et al, 2011). These findings indicate that this rat model fulfills important criteria of face and construct validity, and can be useful to expand our knowledge on the role of NOP receptors in the modulation of behaviors controlled by this peptidergic system.

Here, to better clarify the role of NOP in the modulation of addictive related behaviors, we used this rat line to examine the consequence of genetic deletion of the receptor on the self-administration of some of the most commonly abused drugs, such as cocaine, heroin, and alcohol, under fixed and progressive ratio schedules of reinforcement. Self-administration of the natural reinforcer saccharin was also studied. Finally, using two chemically unrelated selective NOP antagonists, namely LY2817412 and SB-612111 (Rizzi et al, 2007; Toledo et al, 2014), we provided pharmacological confirmation of our findings in NOP receptor $(-/-)$ rats.

\section{MATERIALS AND METHODS}

\section{Animals}

NOP receptor $(-/-)$ rats were in-licenced from Genoway (Lion, France) and were bred at the University of Camerino. This rat line was originally generated at the Hubrecht Institute (The Netherlands) by target-selected ENU-induced mutagenesis on a Brown Norway background (Homberg et al, 2009). Heterozygous mutants were then outcrossed onto a Wistar Han to eliminate confounding effects from other mutations that may have been induced by the ENU mutagenesis. Biochemical characterization revealed that the NOP receptor is completely absent in homozygous knockout rats, and no adaptive change in other opioid receptor levels and distribution has occurred (Homberg et al, 2009).

Although Wt littermates for NOP $(-/-)$ were not available, Wt controls (Wistar Han rats) were purchased from Charles River (Calco, Italy) and maintained at the University of Camerino. To attenuate potential bias linked to this litter effect, careful attention was made to maintain the two rat lines under identical environmental conditions throughout the study. Nonetheless, confounding factors even though minimal associated with lack of littermates cannot be fully excluded.

At the beginning of the experiments, animals' body weight ranged between 200 and $250 \mathrm{~g}$. They were housed in groups of two in a room with artificial $12: 12 \mathrm{~h}$ light/dark cycle (lights off at 09:00 hours), constant temperature $\left(20-22^{\circ} \mathrm{C}\right.$ ) and humidity (45-55\%). All animals were handled once daily for $5 \mathrm{~min}$ for 1 week before the beginning of the experiments. During the entire period of the experimental phase, rats were offered free access to tap water and food pellets (4RF18, Mucedola, Settimo Milanese, Italy). Experiments were performed during the dark phase of the light/dark cycle. All procedures were conducted in adherence to the 'European Community Council Directive for Care and Use of Laboratory Animals'. 


\section{Intravenous Surgery}

For intravenous (IV) surgery, incisions were made to expose the right jugular vein and the back between the shoulders; a catheter made from micro-renathane tubing (I.D. $=0.020 \mathrm{in}$, O.D. $=0.037 \mathrm{in}$; Braintree Scientific) was subcutaneously positioned between these two points. After insertion into the vein, the proximal end of the catheter was anchored to the muscles underlying the vein with surgical silk sutures. The distal end of the catheter was attached to a stainless-steel cannula bent at a $90^{\circ}$ angle. The cannula was inserted in a support made by dental cement and covered with a plastic cap. For 1 week after surgery, rats received daily injections of $0.2 \mathrm{ml}$ of the antibiotic sodium cefotaxime $(262 \mathrm{mg} / \mathrm{ml})$. For the duration of the experiments catheters were flushed daily with $0.2-0.3 \mathrm{ml}$ of heparinized saline solution. Body weights were monitored every two days and catheter patency was confirmed approximately every 7 days with an injection of $0.2-0.3 \mathrm{ml}$ of thiopental sodium $(250 \mathrm{mg} / \mathrm{ml})$ solution. Patency of the catheter was assumed if there was an immediate loss of reflexes. Self-administration sessions began 1 week after surgery.

\section{Drugs}

Cocaine hydrochloride (Johnson Matthey, Edinburgh, UK) was dissolved in sterile physiological saline $(0.9 \% \mathrm{NaCl})$ at a concentration of $0.125,0.25$, and $0.5 \mathrm{mg} /$ infusion. It was given IV for the self-administration experiments. For the CPP experiment, cocaine at the dose of $10 \mathrm{mg} / \mathrm{kg}$ was administered intraperitoneally. Heroin was purchased by SALARS (Como, Italy), and dissolved in sterile saline solution $(0.9 \% \mathrm{NaCl})$ at the concentration of $20 \mu \mathrm{g} / 0.1 \mathrm{ml}$ and given IV. Alcohol drinking solution 10\% (v/v) was prepared by dilution of ethanol $95 \%$ (v/v; F.L. Carsetti s.n.c. Camerino, Italy) in tap water. Saccharin drinking solution $0.2 \%(\mathrm{w} / \mathrm{v})$ was prepared by dissolving saccharin sodium salt hydrate $98 \%$ (Sigma-Aldrich) in tap water. Two selective NOP receptor antagonists, SB-612111 [(-)-cis-1-methyl-7[[4-(2,6-dichlorophenyl)piperidin-1-yl]methyl]-6,7,8,9-tetrahydro-5H-benzocyclohepten-5-ol $]$ and LY2817412 [2'chloro-4' $4^{\prime}$-difluoro-1-\{[1-(3-fluoropyridin-2-yl)-3-methyl$1 \mathrm{H}$-pyrazol-4-yl]methyl $\}-4^{\prime}, 5^{\prime}$-dihydrospiro[piperidine-4,7'thieno[2,3-C]pyran]2,3-dihydroxybutanedioate], were synthesized at Lilly Research Laboratories according to previously published methods and dissolved in a formulation that consisted of a 1:1 mixture of distilled water and $1 \mathrm{M} \mathrm{H}_{3} \mathrm{PO}_{4}$ (Spagnolo et al, 2007; Toledo et al, 2014). The compounds were first wet with $20 \%$ of water. The remaining portion of water and the $1 \mathrm{M} \mathrm{H}_{3} \mathrm{PO}_{4}$ solution were gradually added. Gentle warming in a $45-60^{\circ} \mathrm{C}$ water bath was used in order to completely dissolve the compound until a clear and homogeneous solution was achieved. It was freshly prepared every test day and administered orally in a volume of $3 \mathrm{ml} / \mathrm{kg}$ via gavage.

\section{Self-Administration Apparatus}

The self-administration stations consisted of operant conditioning chambers (Med Associates, St Albans, VT) enclosed in sound attenuating, ventilated environmental cubicles. Each chamber was equipped with a drinking reservoir (volume capacity: $0.30 \mathrm{ml}$ ), positioned $4 \mathrm{~cm}$ above the grid floor in the center of the front panel of the chamber, and two retractable levers (the drug-paired active lever and the inactive control lever) located $3 \mathrm{~cm}$ to the right and to the left of the drinking reservoir. Fluid delivery, count of the number of lever presses and presentation of visual stimuli (illumination of a cue light) were controlled by an IBMcompatible computer. Cocaine and heroin solutions were delivered by a plastic tube that was connected with the catheter before the beginning of the session, whereas alcohol and saccharin solutions were delivered in the drinking reservoir. An infusion pump was activated by responses on the right (active) lever and resulted in a delivery of $0.1 \mathrm{ml}$ of fluid, whereas responses on the left (inactive) lever were recorded but did not result in any programmed consequences.

\section{CPP Apparatus}

The CPP chambers consisted of two equally sized compartments $(30 \times 30 \times 30 \mathrm{~cm})$ with distinct tactile and visual cues (one compartment had a black floor with an equally spaced stainless-steel stripe-like grid on the top, and white walls with black vertical stripes, the other compartment had a white floor and walls with horizontal black stripes), which were separated by a guillotine door. The CPP chambers were positioned in a dark room and two red lamps were positioned at the adjacent angles.

\section{Cocaine and Heroin Self-Administration under Fixed Ratio 1 Schedule of Reinforcement}

After IV catheter implantation, Wt and NOP (-/-) rats were left for one week in their home cages in order to recover from surgery. Animals were then trained to self-administer cocaine $(0.125,0.25$, and $0.5 \mathrm{mg} / 0.1 \mathrm{ml})$ or heroin $(20 \mu \mathrm{g} /$ $0.1 \mathrm{ml}$ ) under a fixed ratio 1 (FR1) with $20 \mathrm{~s}$ time-out (TO) schedule of reinforcement, in which each response at the drug-paired active lever resulted in the IV delivery of $0.1 \mathrm{ml}$ of fluid, whereas responses at the inactive lever resulted in no fluid delivery (Kallupi et al, 2010). Rats received $2 \mathrm{~h}$ daily sessions for 13-14 consecutive days.

\section{Cocaine and Heroin Self-Administration under Progressive Ratio Schedule of Reinforcement}

Animals were first trained to FR1 self-administration until stable baseline of responding was achieved. Rats were then tested under a progressive ratio (PR) schedule of reinforcement to measure the breakpoint (BP), defined as the last ratio completed by the animal for the acquisition of the next reward. The number of lever responses or the ratio required to receive one dose of cocaine was increased as follows: 5,11 , $18,26,35,45,56,68,82,98,116,136,158,182,208,236,268$, 304. Additional groups of rats were employed for heroin selfadministration. As for cocaine, these animals were first trained under an FR1 schedule of reinforcement and then were switched to a PR schedule where the response requirements necessary to receive a single reward increased according to the following progression: 1, 2, 4, 6, 9, 12, 15, 20, $25,32,40,50,62,77,95,118,145,178,219,268$, and so on (de Guglielmo et al, 2015b; Richardson and Roberts, 1996). 
Table I NOP Antagonist in vitro Receptor-Binding Affinity $\left(K_{i}\right)$ and Functional Antagonist Potency $\left(K_{b}\right)$

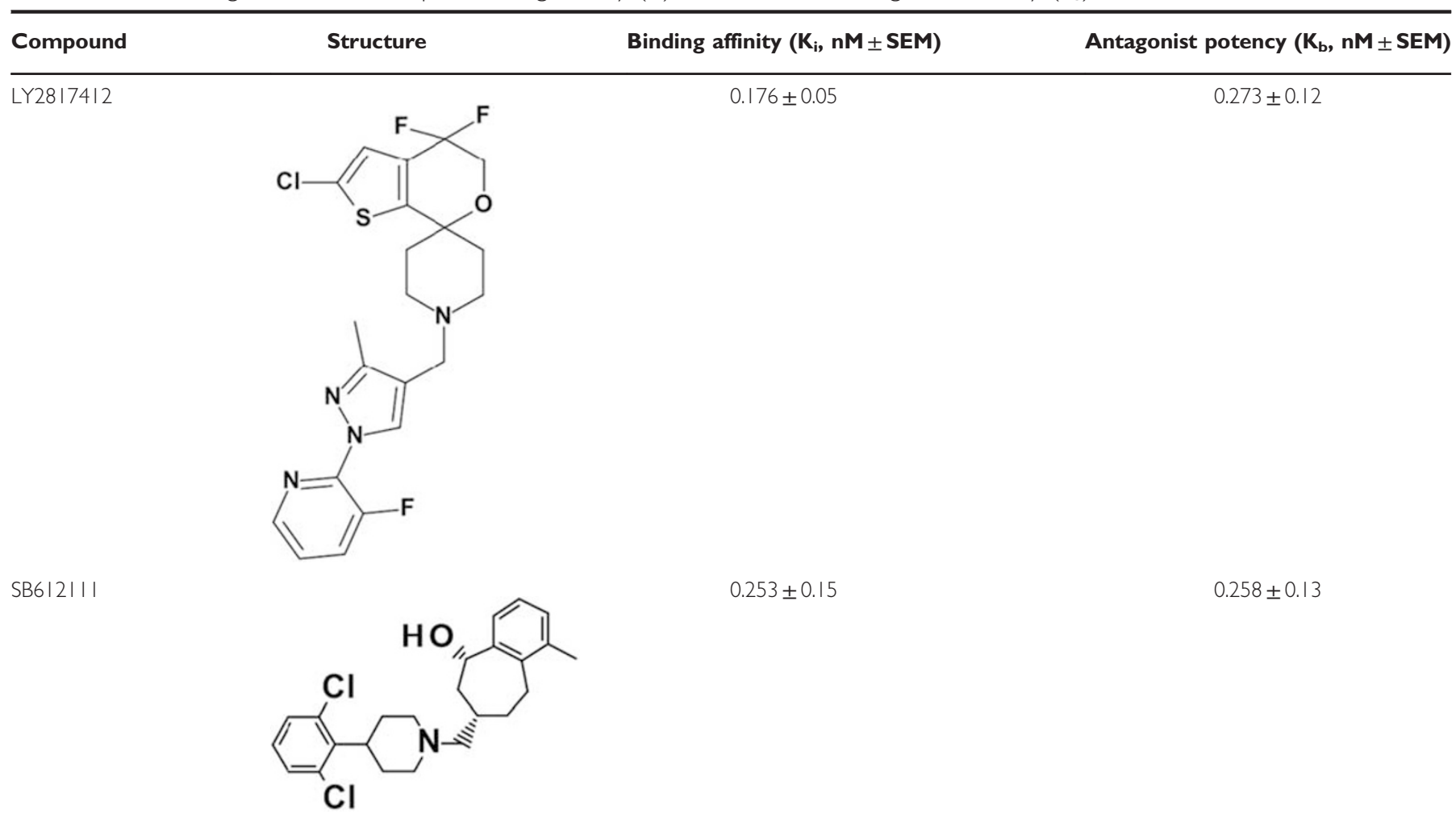

The sessions were terminated when $>60 \mathrm{~min}$ had elapsed since the last reinforced response. The PR is an operant schedule that allows measuring the maximum amount of work an animal is willing to carry out to obtain the reward, reflecting its motivation for it.

\section{Acquisition of Alcohol and Saccharin Self-Administration}

$\mathrm{Wt}$ and NOP (-/-) rats were trained to self-administer ethanol $(10 \% \mathrm{v} / \mathrm{v})$ or saccharin $(0.2 \% \mathrm{w} / \mathrm{v})$ solution in $30 \mathrm{~min}$ daily sessions under an FR1 schedule of reinforcement, in which each response at the active lever resulted in the delivery of $0.1 \mathrm{ml}$ of fluid, whereas responses at the inactive lever resulted in no fluid delivery. Each reward delivery was associated with $5 \mathrm{~s}$ time-out (TO $5 \mathrm{~s}$ ) signaled by illumination of the cue light. Alcohol or saccharin selfadministration training continued until stable baselines of responding were established. To facilitate acquisition of lever pressing for alcohol, a classical saccharin fading procedure was used during which ethanol concentration was progressively increased to reach $(10 \% \mathrm{v} / \mathrm{v})$ and saccharin progressively removed from the fluid. Water and food were freely available in the home cages during the entire experimental period.

\section{Alcohol and Saccharin Self-Administration under PR}

After the completion of alcohol and saccharin-acquisition phase, rats were tested under a PR schedule of reinforcement to measure the $\mathrm{BP}$ for alcohol and saccharin. For this purpose, animals previously trained to FR1 (10\% v/v) alcohol or saccharin $(0.2 \% \mathrm{w} / \mathrm{v})$ solution self-administration, were then tested under PR contingency, in which the response requirement to receive one dose of ethanol or saccharin was increased as follows: for each of the first four ethanol or saccharin deliveries, the ratio was increased by 1 ; for the next four deliveries the ratio was increased by 2; for all the following deliveries the ratio was increased by 4 . Each reinforced response resulted in a $1 \mathrm{~s}$ illumination of the cue light, whereas sessions were terminated when $>30 \mathrm{~min}$ had elapsed since the last reinforced response (Economidou et al, 2006b).

\section{Effect of the NOP Antagonists SB-612111 and LY2817412 on Ethanol Self-Administration in NOP $(-/-)$ and Wt Rats}

To confirm findings generated in $\operatorname{NOP}(-/-)$ rats, we administered two chemically unrelated highly selective NOP antagonists, SB-612111 and LY2817412 to NOP ( / - ) and $\mathrm{Wt}$ rats and the effect of receptor blockade on alcohol selfadministration was tested. Receptor-binding affinity (Ki) and functional antagonist potency of SB-612111 and LY2817412 (Table 1) were determined in Chinese Hamster Ovary cells expressing the NOP receptor according to previously published methods (Statnick et al, 2016).

After the acquisition of a stable baseline of ethanol self-administration, $\mathrm{Wt}(n=7)$ and NOP $(-/-)(n=8)$ rats were treated orally with SB-612111 $(0.0,3.0$, and $30.0 \mathrm{mg} / \mathrm{kg})$, according to a within-subject Latin square design, in which each animal received in a counterbalanced order all drug 
doses. Drug doses were chosen based on our previous experience with this compound and published data (Rizzi et al, 2007; Toledo et al, 2014).

Before the beginning of the treatment, rats were acclimated to gavage administration procedures for three consecutive days, during which they received distilled water to familiarize them with the injection procedure, after which the experiment began. Drugs or vehicle were administered $60 \mathrm{~min}$ before the beginning of the self-administration session. Tests were performed every 3 days. The day after the experiment, animals were left undisturbed and the subsequent day a new baseline of alcohol self-administration was re-established.

After having completed the experiment with the SB-612111, a new baseline for alcohol self-administration was re-established for 1 week and then the same procedure was repeated to test LY2817412 $(0.0,1.0$, and $10.0 \mathrm{mg} / \mathrm{kg})$. A $10 \mathrm{mg} / \mathrm{kg}$ dose of LY2817412 produced 55\% receptor occupancy of NOP receptors in the brain $24 \mathrm{~h}$ after administration (Toledo et al, 2014).

\section{Cocaine-Induced CPP}

On day 0 (pretest), rats freely explored the two compartments for $15 \mathrm{~min}$, and the time spent in each compartment during the exploratory period was measured. Rats that spent $60-70 \%$ ( $>630 \mathrm{~s})$ of the total time $(15 \mathrm{~min})$ in one side were excluded from the experiment. We used an unbiased-like protocol and we assigned the drug-paired compartment randomly to the rats. On days 1-3 (conditioning), rats were given alternating injections of cocaine $(10 \mathrm{mg} / \mathrm{kg}$, i.p.) or saline ( $1 \mathrm{ml} / \mathrm{kg}$, i.p.) twice daily (0900 hours to 1900 hours) and confined to one compartment for $30 \mathrm{~min}$ for 3 consecutive days. On day 4 (test day), rats were allowed to explore the two compartments freely for $15 \mathrm{~min}$ and the time spent in each compartment during the exploratory period was measured.

\section{Statistical Analysis}

For data evaluation, the analysis of variance (ANOVA) was used followed by Newman-Keuls post hoc tests. In detail, number of rewards in $\mathrm{Wt}$ and NOP $(-/-)$ rats during the acquisition phase of cocaine, heroin, alcohol, and saccharin were analyzed by means of a two-way ANOVA with one factor between (rat line) and one factor within (days/ sessions). For the CPP test, strain was considered as the between factor, whereas treatment (cocaine $v s$ saline) was considered as the within factor. For the PR test, an unpaired Student's $t$-test was used to analyze the rewards acquired by wild-type compared with the NOP $(-/-)$ rats. The effect of SB-612111 and LY2817412 was evaluated by a two-way ANOVA with one factor between (rat line) and one factor within (treatment) followed by Newman-Keuls tests. Statistical significance was set at $P<0.05$.

\section{RESULTS}

\section{NOP (-/ - ) Rats Self-Administer Less Cocaine Compared with Wt Counterparts and have a Reduced Motivation for the Drug}

$\mathrm{Wt}(n=9)$ and NOP $(-/-)$ rats $(n=7)$ were trained to selfadminister cocaine $(0.25 \mathrm{mg} / 0.1 \mathrm{ml}$, IV) for 13 consecutive days in $2 \mathrm{~h}$ daily sessions under the FR1 schedule of reinforcement. ANOVA showed a significant effect of strain $(\mathrm{F}(1,14)=8.46 ; \quad P<0.05)$, significant effect of session $(\mathrm{F}(12,168)=14.77 ; P<0.0001)$ and a significant interaction 'strain $\times$ session' $(\mathrm{F}(12,168)=3.003 ; P<0.001)$. NOP $(-/-)$ rats self-administered significantly less cocaine compared with Wt rats, as revealed by the post hoc Newman-Keuls analysis in days $4,5(P<0.01), 6(P<0.05)$ and $7-13$ $(P<0.001$; Figure 1a). After completion of cocaine acquisition under FR1, Wt and NOP $(-/-)$ rats were switched to a PR schedule of reinforcement. Data analysis by means of unpaired Student's $t$-test showed a reduced number of cocaine reinforcements $\mathrm{t}(14)=3.370, P<0.01)$ in the NOP $(-/-)$ rats compared with the Wt (Figure $1 \mathrm{~b})$.

\section{Reduced Motivation for Cocaine in NOP (-/ - ) Rats does not Depend upon Altered Drug Sensitivity}

To determine whether attenuated cocaine self-administration depends upon a different sensitivity to its rewarding effect, NOP $(-/-)$ and $\mathrm{Wt}$ were tested for multiple drug concentrations. Wt $(n=7)$ and $\operatorname{NOP}(-/-)(n=7)$ rats were trained to self-administer cocaine solution $(0.25 \mathrm{mg} /$
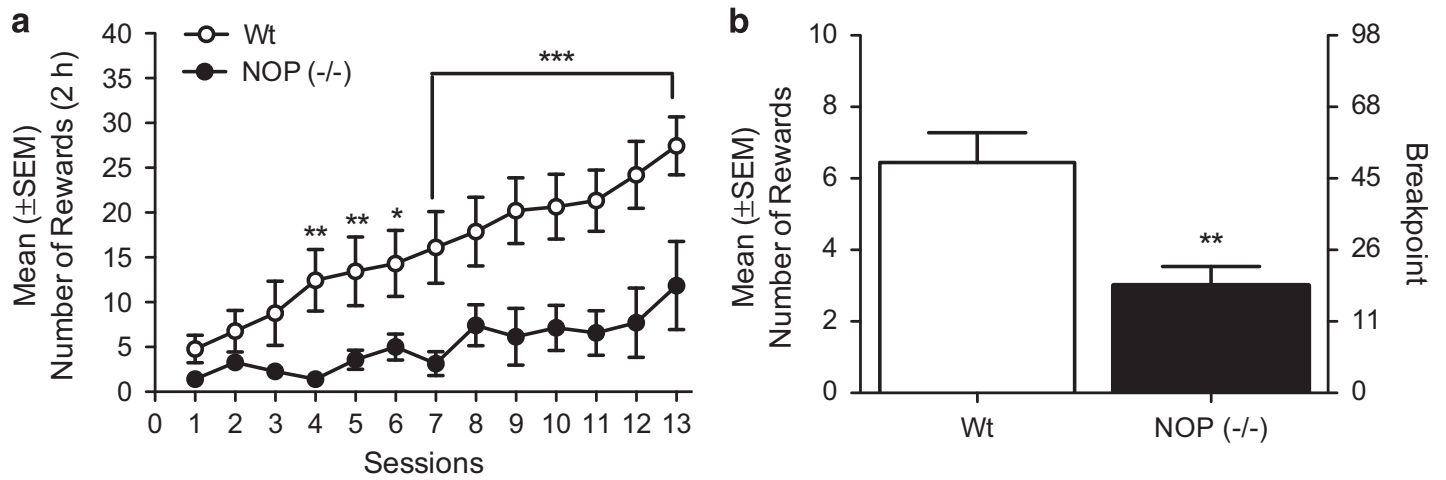

Figure I (a) Acquisition pattern ( 13 days) of cocaine $(0.25 \mathrm{mg} /$ infusion) self-administration in NOP $(-/-; n=7)$ indicated with black circles, and in wildtype $(\mathrm{Wt})$ rats $(n=9)$ in white circles, under an FRI schedule of reinforcement. Results are expressed as mean \pm SEM of number of rewards acquired by animals. (b) Illustrates the mean \pm SEM of number of cocaine infusions (rewards) and mean \pm SEM of the breakpoint (BP) achieved by NOP $(-/-)$ in black column and Wt rats in white column during cocaine self-administration under a progressive ratio schedule of reinforcement, significant difference between Wt and NOP $(-1-)$. **** $P<0.0001 ; * * P<0.01 ; * P<0.05$. 
a

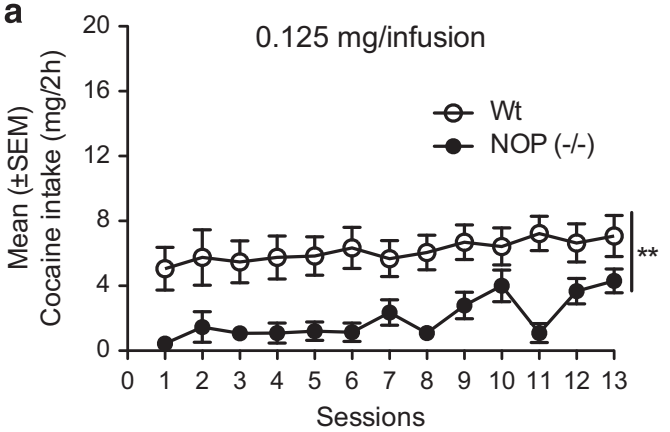

b

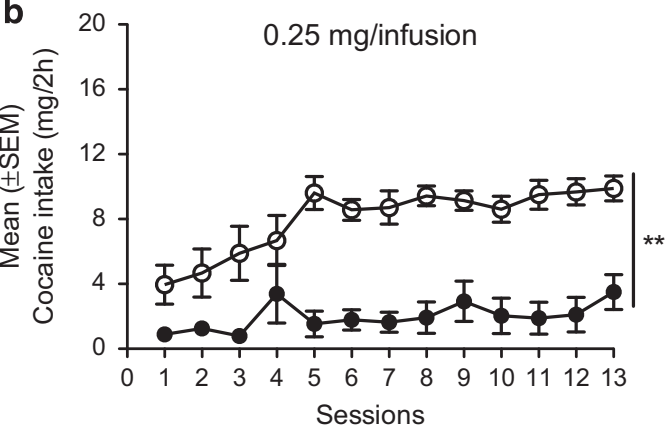

C

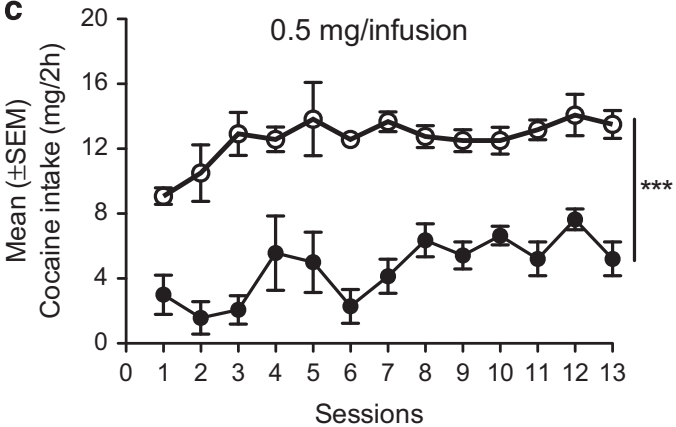

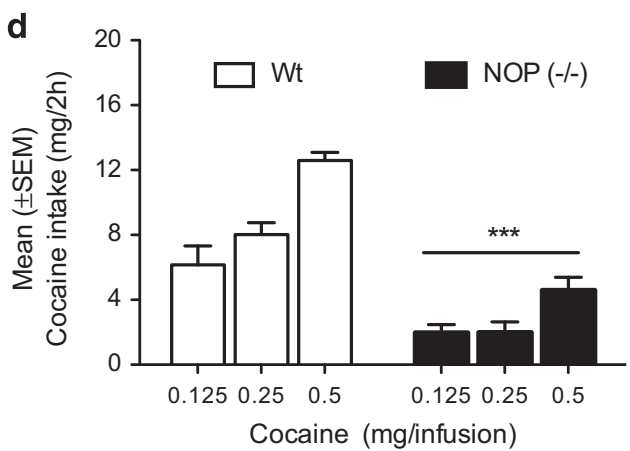
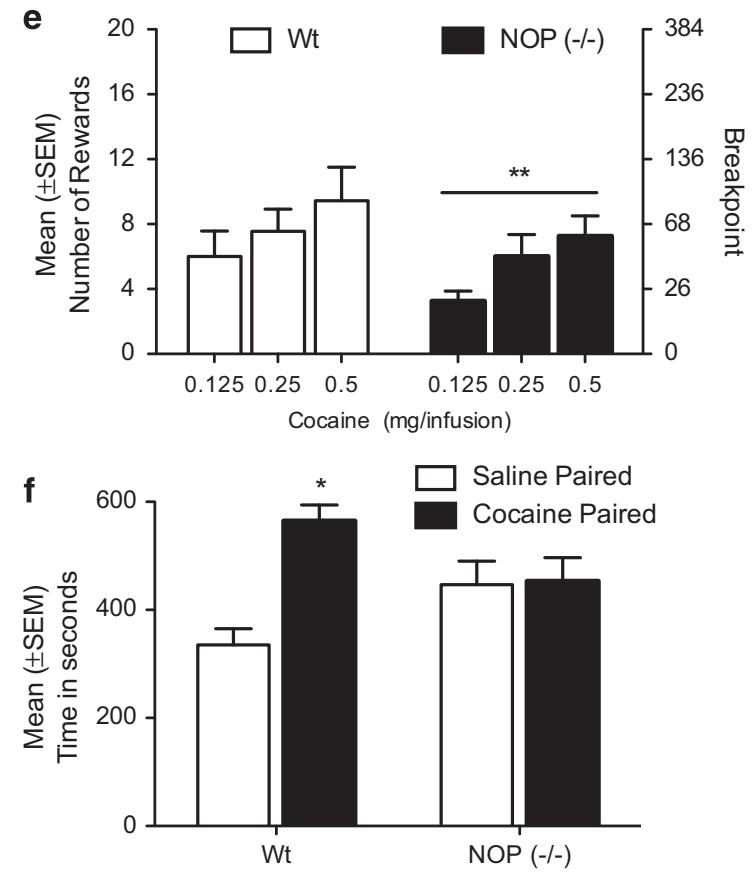

Figure 2 Self-administration pattern registered at different doses (a) 0.125 , (b) 0.25 , and (c) $0.5 \mathrm{mg}$ /infusion of cocaine in Wt rats ( $n=7$ ) shown in white and NOP $(-1-; n=7)$ shown in black. Results are presented as mean \pm SEM of cocaine intake expressed as mg/rat. (d) Dose-effect curve of cocaine selfadministration expressed as mean \pm SEM of cocaine intake measured during the 13 self-administration days in Wt and NOP ( - / - ) rats. (e) IIlustrates the mean \pm SEM breakpoint for different concentrations of cocaine $(0.125,0.25$, and $0.5 \mathrm{mg} /$ infusion) in NOP $(-/-)$ and Wt rats during cocaine selfadministration under a progressive ratio schedule of reinforcement. Significant difference between rat lines or cocaine doses. $* * * P<0.000 \mathrm{I}$; $* * P<0.01$. (f) Place conditioning effects of cocaine in Wt rats $(n=10)$ and NOP $(-1-; n=10)$. Place preference was calculated as time spent in the cocaine $(10 \mathrm{mg} / \mathrm{kg})$ paired minus time spent in the saline-paired compartment on test day. Test was carried out using an unbiased procedure in which half of the rats were conditioned to cocaine in one compartment of the arena and the other half to the other. Significant difference saline- and cocaine-paired compartments in Wt and $\operatorname{NOP}(-/-)$. *P $<0.05$.

$0.1 \mathrm{ml}, \mathrm{IV}$ ) for 13 consecutive days in $2 \mathrm{~h}$ daily sessions under the FR1 schedule of reinforcement. Once stable baseline of cocaine self-administration was reached, animals were switched to a PR schedule of reinforcement. At this point, half of the rats were switched to the lowest concentration of cocaine $(0.125 \mathrm{mg} / 0.1 \mathrm{ml}, \mathrm{IV})$ and half to the highest concentration $(0.5 \mathrm{mg} / 0.1 \mathrm{ml}$, IV). Sessions under FR1 contingency continued for an additional 13 consecutive days, subsequently the PR performances were recorded. The procedure was repeated by switching the rats from the lowest to the highest dose and vice versa so that all rats received all cocaine concentrations (Figure 2). A two-way ANOVA with 'strain' as a between factor and 'session' as a within factor was performed to separately analyze the amount of cocaine acquired (expressed in $\mathrm{mg}$ ) at the three concentrations of cocaine tested. For the lowest cocaine concentration $(0.125 \mathrm{mg} / 0.1 \mathrm{ml}$, IV $)$, statistical analysis revealed a significant effect of strain $(\mathrm{F}(1,12)=10.75$; $P<0.01)$, session $(\mathrm{F}(12,144)=7.55 ; P<0.001)$ and 'strain $\times$ session' interaction $(F(12,144)=2.77 ; P<0.01$; Figure 2a). Similar results were obtained for the intermediate concentration $(0.25 \mathrm{mg} / 0.1 \mathrm{ml}$, IV) where the two-way ANOVA revealed an effect of strain $(\mathrm{F}(1,12)=11.43 ; P<0.01)$, session $(\mathrm{F}(12,144)=6.33 ; P<0.001)$ and 'strain $\times$ session' interaction $(\mathrm{F}(12,144)=4.326 ; \quad P<0.05 ; \quad$ Figure $2 \mathrm{~b})$. When selfadministration data from the highest dose $(0.5 \mathrm{mg} / 0.1 \mathrm{ml}$, IV) were analyzed, we found a significant effect of strain $(\mathrm{F}(1,11)=67.17 ; \quad P<0.001)$ and session $(\mathrm{F}(12,132)=4.29$; $P<0.001)$ but the interaction term was not significant $(\mathrm{F}(12,132)=1.40 ; P=\mathrm{NS} ;$ Figure $2 \mathrm{c})$. During this latter 
phase, one Wt rat lost the catheter and it was excluded from the statistical analysis.

In a subsequent analysis, when ANOVA was used to evaluate the difference between $\mathrm{Wt}$ and NOP $(-/-)$ rats in average cocaine intake at different concentrations for the entire 13 session period, a significant effect of strain $(\mathrm{F}(1,11)=86.13 ; \quad P<0.001)$ and cocaine dose $(\mathrm{F}(2$, $22)=18.49 ; P<0.001)$ were confirmed, but no effect of the interaction 'strain $\times$ cocaine concentration' was found $(\mathrm{F}(2,22)=2.65 ; \quad P<0.05)$. The post hoc Newman-Keuls analysis confirmed that, compared with Wt rats, NOP $(-/-)$ rats self-administered significantly less cocaine at all concentrations tested $(P<0.001$; Figure $2 \mathrm{~d})$.

When PR response at different concentrations of cocaine was evaluated, results analyzed by two-way ANOVA with 'strain' as a between factor and 'cocaine concentration' as a within factor showed a significant effect of strain $(\mathrm{F}(1,11)=13.43 ; P<0.01)$, a trend to an effect of concentrations $(\mathrm{F}(2,22)=3.03 ; P=0.06)$ and no 'strain $\times$ cocaine concentration' interaction $(\mathrm{F}(2,22)=0.34 ; P=0.7)$. As shown in Figure 2e, NOP $(-/-)$ showed a marked reduction in the number of cocaine rewards achieved $(P<0.01)$.

\section{Cocaine Induces CPP in the Wt but not in NOP $(-/-)$ Rats}

Wt $(n=10)$ and NOP $(-/-)$ rats $(n=10)$ previously conditioned for cocaine were tested for $15 \mathrm{~min}$ in the CPP test. The CPP effect was determined by analyzing the time spent in the cocaine $v s$ saline-paired compartment in the test day. ANOVA showed a significant difference of treatment $(\mathrm{F}(1,18)=4.98 ; \quad P<0.05)$, and a significant interaction 'strain $\times$ treatment' $\quad(\mathrm{F}(1,18)=4.44 ; \quad P<0.05)$. Post hoc Newman-Keuls analysis revealed that the $\mathrm{Wt}$ rats spent more time in the cocaine-paired compartment compared with the saline-paired one $(P<0.05)$, whereas no difference between the time spent in cocaine or saline-paired compartment was observed in the NOP $(-/-)$ counterpart (Figure 2f).

\section{NOP ( $/-$ ) Rats Self-Administer Less Heroin Compared with Wt Counterparts and have a Reduced Motivation for the Opioid}

Wt $(n=11)$ and NOP $(-/-)$ rats $(n=10)$ were trained to self-administer heroin $(20 \mu \mathrm{g} / 0.1 \mathrm{ml}, \mathrm{IV})$ for 14 consecutive days in $2 \mathrm{~h}$ daily sessions under the FR1 schedule of reinforcement until baseline was reached. ANOVA revealed a significant effect of strain $(\mathrm{F}(1,19)=21 ; P<0.001)$, number of sessions $(\mathrm{F}(13,247)=21.9 ; P<0.0001)$, and a significant 'strain $\times$ session' interaction $(\mathrm{F}(13,247)=2.9 ; \quad P<0.001)$. NOP $(-/-)$ rats self-administered significantly less heroin solution compared with the Wt rats and Newman-Keuls post hoc analysis showed a significant difference in sessions 1 and $4(P<0.05)$, and a highly significant difference for the rest of the sessions $(P<0.001$; Figure $3 a)$.

Once stable baseline of responding under FR1 was established, Wt and NOP $(-/-)$ rats were tested in a PR schedule of reinforcement. Statistical analysis by means of unpaired Student's $t$-test showed a significant reduction in the $P R$ responding for heroin $t(19)=2.526, P<0.05)$ in NOP $(-/-)$ rats compared with the Wt rats (Figure $3 \mathrm{~d}$ ).
Acquisition of Alcohol Self-Administration in NOP $(-I-)$ vs Wt Rats

Wt $(n=8)$ and NOP $(-/-)$ rats $(n=7)$ were trained to self-administer $10 \% \quad(\mathrm{v} / \mathrm{v})$ ethanol in $30 \mathrm{~min}$ daily sessions under the FR1 schedule of reinforcement. ANOVA revealed a significant effect of strain $(F(1,13)=20.72$; $P<0.001)$ but no effect of session $(\mathrm{F}(13,169)=2.6$; $P=\mathrm{NS})$ or 'strain $\times$ sessions' interaction $(\mathrm{F}(13,169)=2.79$; $P=$ NS; Figure $3 \mathrm{~b})$, reflecting the fact that throughout the test period, NOP $(-/-)$ rats self-administered less alcohol than $\mathrm{Wt}$.

After acquisition of stable baseline alcohol selfadministration under FR1, Wt and $\operatorname{NOP}(-/-)$ rats were tested in a PR schedule of reinforcement. Unpaired Student's $t$-test revealed significantly fewer number of alcohol rewards $\mathrm{t}(12)=4.133, P<0.01)$ in the $\operatorname{NOP}(-/-)$ rats compared with $\mathrm{Wt}$ counterparts (Figure $3 \mathrm{e}$ ). In the PR experiment, one $\mathrm{Wt}$ rat was excluded because of health issues, consequently this test was carried out with $7 \mathrm{Wt}$ and $7 \operatorname{NOP}(-/-)$.

NOP ( $/-)$ and Wt Rats do not Differ in Saccharin SelfAdministration

Wt $(n=9)$ and NOP $(-/-)$ rats $(n=9)$ were trained to selfadminister $(0.2 \% \mathrm{w} / \mathrm{v})$ saccharin solution under an FR1 schedule of reinforcement in $30 \mathrm{~min}$ daily sessions for 13 days. ANOVA did not show any significant difference in saccharin self-administration between lines (F $(1,16)=1.29 ; P=\mathrm{NS})$. Lever pressing for saccharin progressively increased over days leading to a significant effect of time $(\mathrm{F}(12,192)=52.84 ; P<0.0001)$. ANOVA failed to detect any significant 'strain $\times$ session' interaction $(\mathrm{F}(12,192)=0.79$; $P=$ NS; Figure $3 \mathrm{c}$ ).

After completion of FR1 saccharin self-administration, $\mathrm{Wt}$ and NOP $(-/-)$ rats were tested under a PR schedule of reinforcement to measure the motivation for saccharin. Unpaired Student's $t$-test showed no statistically significant difference $\mathrm{t}(16)=0.93, P=\mathrm{NS})$ between NOP $(-I-)$ and Wt rats (Figure $3 \mathrm{f}$ ).

\section{NOP Antagonism Reduces Alcohol Self-Administration} in $\mathrm{Wt}$, but not in NOP $(-/-)$ Rats

Analysis of the number of rewards acquired, revealed a significant effect of line $(\mathrm{F}(1,13)=20.5 ; \quad P<0.001)$, treatment $(\mathrm{F}(2,26)=5,42 ; P<0.05)$, and 'strain $\times$ treatment' interaction $(\mathrm{F}(2,26)=4.27 ; P<0.05)$. Post hoc NewmanKeuls analysis showed that Wt self-administered significantly higher amounts of ethanol compared with NOP $(-/-)$ rats $(P<0.001)$. To test the effects of NOP receptor blockade on alcohol self-administration, we employed two potent small-molecule antagonists (Table 1). SB-612111, at both doses tested ( 3 and $30 \mathrm{mg} / \mathrm{kg}$ ) significantly reduced the number of alcohol rewards in the Wt rats $(P<0.01)$, but did not affect alcohol intake in the NOP $(-/-)$ rats (Figure 4a).

The effect observed with SB-612111 was then confirmed using LY2817412. Indeed, overall two-way ANOVA revealed a significant line difference $(F(1,13)=13.3$; $P<0.01)$ and a significant 'strain $\times$ treatment' interaction $(\mathrm{F}$ 
Heroin
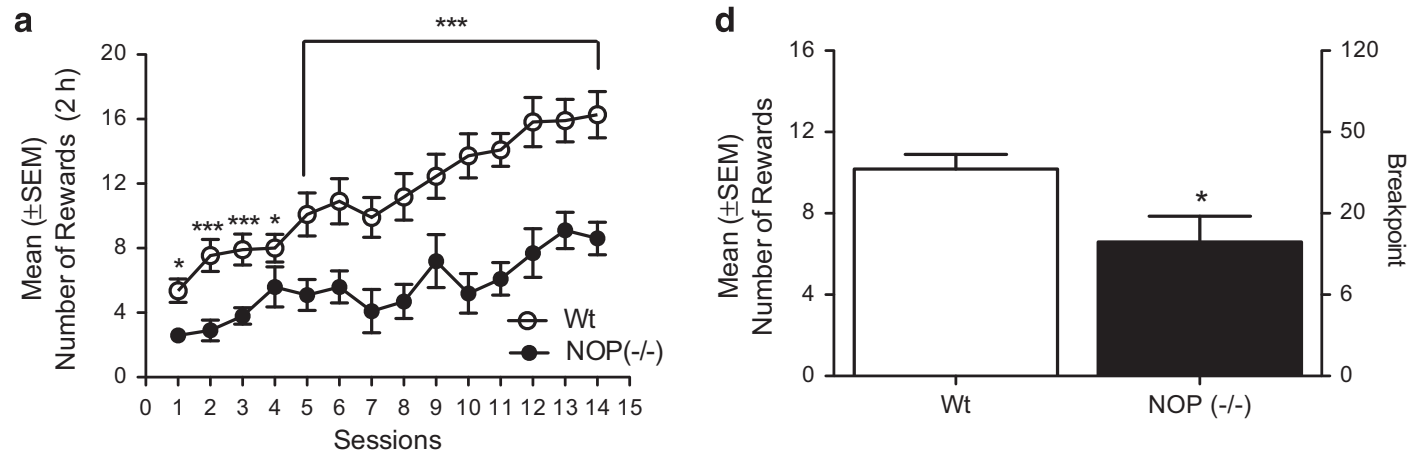

Ethanol
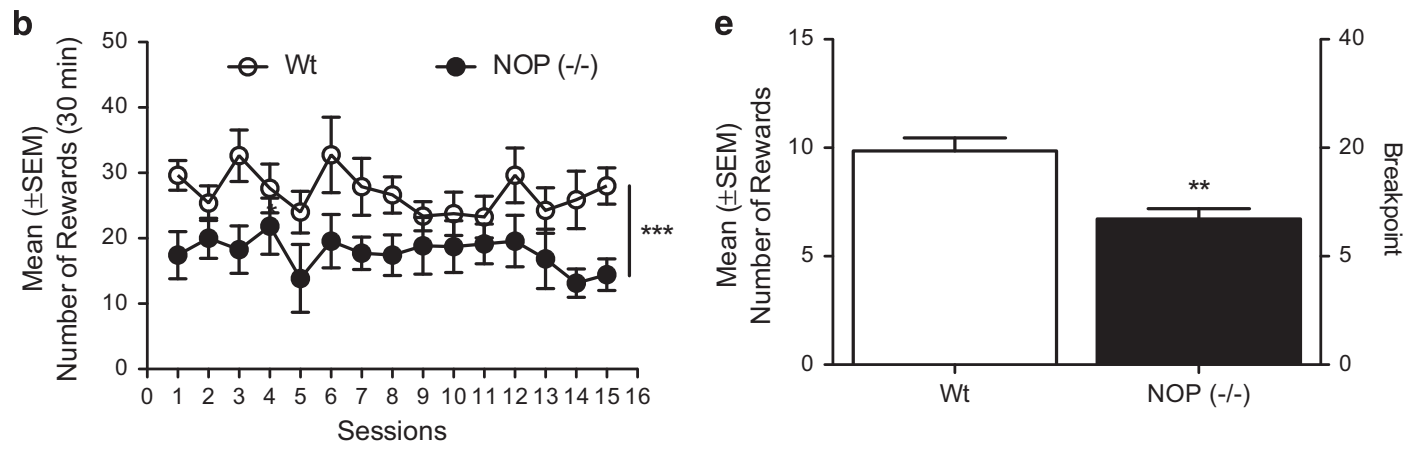

Saccharin
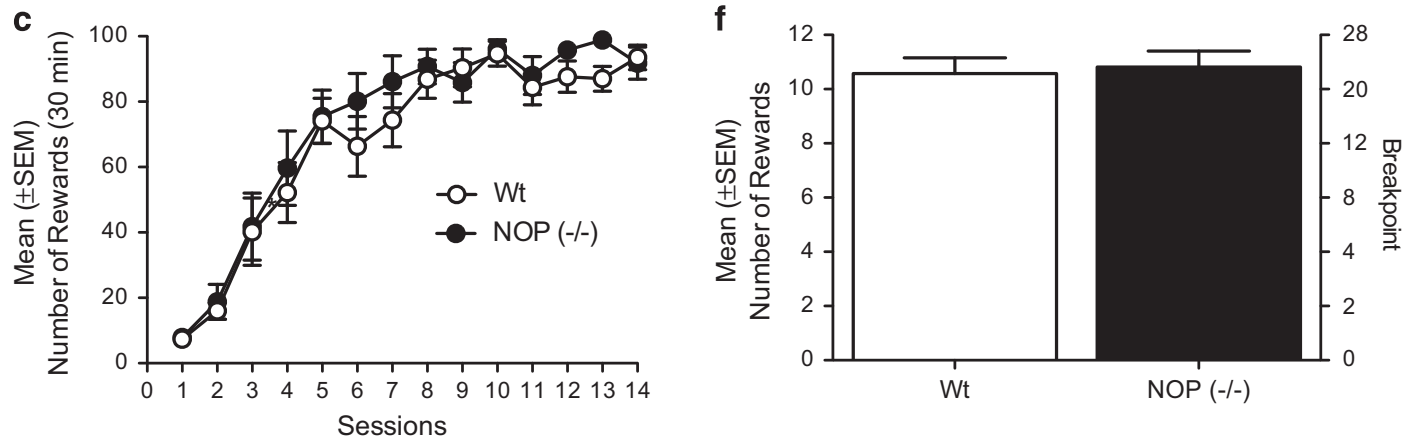

Figure 3 (a) Acquisition pattern ( 14 days) of heroin self-administration in NOP $(-/-; n=10)$ in black circles and in Wt rats ( $n=1 \mathrm{I})$ in white circles under an FRI schedule of reinforcement. Results are expressed as mean \pm SEM of numbers of rewards acquired by rats. Significant difference between rat lines. **** $P<0.000$ I; $* P<0.05$. (b) Acquisition pattern (I 5 days) of alcohol self-administration in NOP $(-/-; n=7)$ and in Wt rats ( $n=8)$ under an FRI schedule of reinforcement. Results are expressed as mean \pm SEM of numbers of rewards $(0.1 \mathrm{ml}$ of I $0 \%$ ethanol) acquired by animals. Significant difference between rat lines. ${ }^{*} * * P<0.000 I$. (c) Acquisition pattern ( 14 days) of saccharin $(0.2 \%)$ self-administration in NOP $(-/-; n=9)$ and in Wt rats $(n=9)$ under a FRI schedule of reinforcement. Results are expressed as mean \pm SEM of numbers of rewards $(0.1 \mathrm{ml}$ of $0.2 \%$ saccharin) acquired by animals. (d) Illustrates the mean \pm SEM of number of heroin infusions (rewards) and mean \pm SEM of the breakpoint achieved by NOP $(-/-)$ and Wt rats during heroin selfadministration under a progressive ratio schedule of reinforcement. Significant difference between Wt and NOP $(-/-)$. $* P<0.05$. (e) Illustrates the mean \pm SEM of number of ethanol deliveries (rewards) and mean \pm SEM of the breakpoint achieved by NOP $(-/-)$ and Wt rats during ethanol selfadministration under a progressive ratio schedule of reinforcement. Significant difference between Wt and NOP $(-/-)$. *** $<0.01$. ( $f$ ) Illustrates the mean \pm SEM of number of saccharin deliveries (rewards) and mean \pm SEM of the breakpoint achieved by NOP $(-/-)$ and Wt rats during saccharin selfadministration under a progressive ratio schedule of reinforcement.

$(2,26)=3.78 ; P<0.05)$, but no main effect of treatment $(\mathrm{F}(2,26)=2.19 ; \quad P=\mathrm{NS} ;$ Figure $4 \mathrm{~b})$. Post hoc analysis confirmed that Wt rats self-administered significantly higher levels of alcohol compared with NOP $(-/-)$ rats $(P<0.01)$. Moreover, results indicated that LY2817412 significantly attenuated alcohol consumption in Wt rats (at the $10 \mathrm{mg} / \mathrm{kg}$ dose), but not in NOP $(-/-)$ rats at any dose tested (Figure $4 \mathrm{~b}$ ).

\section{DISCUSSION}

The main finding of the present study was that NOP $(-/-)$ rats showed reduced propensity to self-administer cocaine, heroin, and alcohol, compared with outbred controls. These drugs have distinct psychoactive effects and different mechanisms of action, nevertheless, their intake was significantly blunted following NOP receptor deletion, 
a

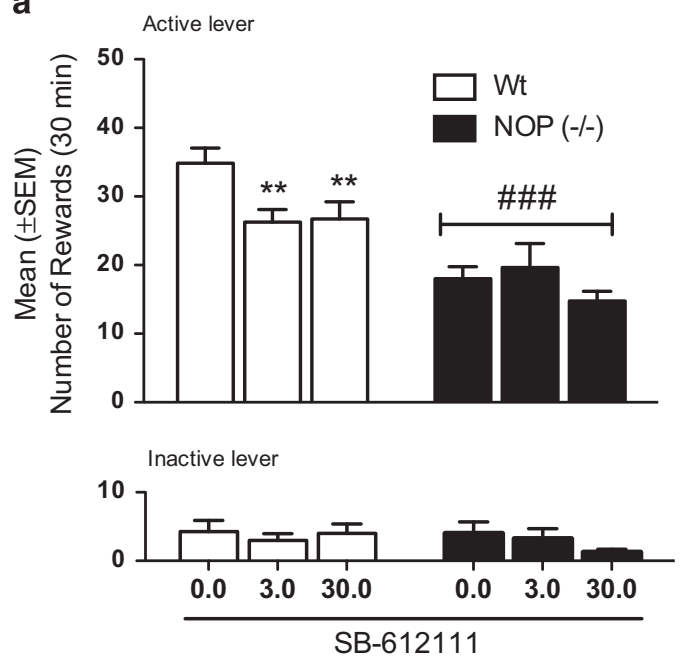

b

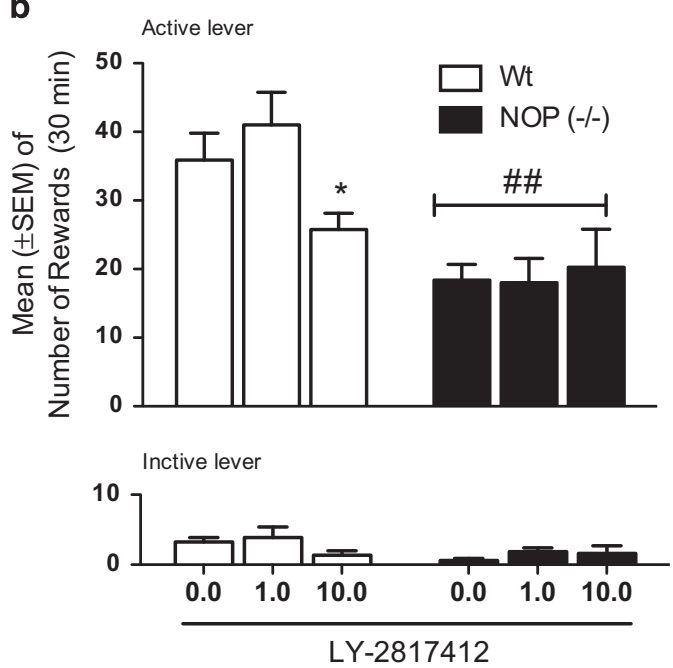

Figure 4 (a) Effect of the selective NOP receptor antagonist SB-6/2III (0.0, 3.0, and $30.0 \mathrm{mg} / \mathrm{kg}$ ) on I0\% ethanol self-administration in NOP ( $-/-$; $n=8)$ in black columns and in Wt rats $(n=7)$ shown in white columns. (b) Effect of the selective NOP receptor antagonist LY28I74I2 (0.0, 3.0 , and I 0.0 mg/ $\mathrm{kg}$ ) on $10 \%$ ethanol self-administration in NOP $(-/-)$ and in Wt rats. Results are expressed as mean \pm SEM of numbers of rewards $(0.1 \mathrm{ml}$ of $10 \%$ ethanol) acquired by animals. Differences between Wt and NOP $(-/-)$ rats. ${ }^{\prime \prime} P<0.001 ;{ }^{\prime} P<0.01$. Differences between vehicles and drug-treated groups. $* * P<0.01$ and $* P<0.05$.

suggesting that this receptor has a remarkable role in the regulation of drug reward. We also tested NOP $(-/-)$ rats for saccharin self-administration; in this case, we did not find differences compared with Wt counterparts, indicating that deletion of NOP receptors does not affect the motivation for natural reinforcers. The lack of effect on saccharin selfadministration rules out the possibility that the altered response toward drugs of abuse in NOP $(-/-)$ rats was dependent upon reduced activation of brain reward circuitry, nonspecific locomotor deficits, or learning impairment.

\section{NOP (-I-) Rats Show Reduced Propensity to Self- Administer Cocaine, Heroin, and Alcohol, Compared with Outbred Controls}

Theoretically, drug self-administration between NOP ( - / - ) and $\mathrm{Wt}$ rats could differ due to differences in pharmacokinetic mechanisms responsible for the absorption, metabolism, or excretion of the various drugs. Although direct measurements of brain or cerebrospinal fluids levels of drugs were not compared in NOP $(-/-)$ and Wt rats, it is highly unlikely that the different intake observed is due to pharmacokinetic factors, considering that the pathways through which these drugs are metabolized and excreted are different.

Alternatively, it is possible that NOP receptor deletion shifted the reward threshold of drug self-administration. To test this possibility, we evaluated the self-administration of increasing concentrations of cocaine in $\operatorname{NOP}(-/-)$ and $\mathrm{Wt}$ controls. In rats, the standard training dose of cocaine (0.25 mg/infusion) robustly maintained operant responding under both FR and PR contingencies. At lower concentrations $(0.125 \mathrm{mg} /$ infusion$)$, cocaine-related lever pressing was also maintained but with blunted reinforcing effects. Conversely, at the highest concentration ( $0.5 \mathrm{mg} /$ infusion $)$ tested, this psychostimulant reached its maximal reinforcing potential. Results described in the present work align with historically reported reinforcing effects of cocaine (Semenova and Markou, 2003), specifically that cocaine intake and BP measured in both $\mathrm{Wt}$ and NOP $(-/-)$ rats were lowest at $0.125 \mathrm{mg} /$ infusion and highest at $0.5 \mathrm{mg} /$ infusion. Most importantly, despite the fact that direct parametric analysis of dose difference were not carried out, we observed that, regardless of the concentration of cocaine tested, NOP $(-/-)$ rats always self-administered less drug and reached lower BP compared with their Wt counterpart.

These data strongly suggest that differences in cocaine selfadministration were not dependent upon changes in drug sensitivity. This interpretation cannot be directly applied to understanding the role of NOP in the modulation of the reinforcing effects of alcohol and heroin, for which we did not run dose-response curves. However, considering the data on cocaine, together with the fact that motivation for saccharin was not altered by NOP receptor deletion, it is unlikely that changes in reward threshold are responsible for the reduced propensity to self-administer drugs of abuse by NOP $(-/-)$ rats.

\section{NOP Antagonists Attenuate Ethanol Drinking in Wt Rats, but not in the NOP $(-/-)$ Rats}

To strengthen our observation and to provide a complementary analysis of the data obtained in NOP $(-/-)$ rats, we used a pharmacological approach. In particular, we tested the effect of two chemically unrelated highly selective NOP antagonists, namely SB-612111 and LY2817412 on operant alcohol self-administration (Rizzi et al, 2007; Toledo et al, 2014). Results revealed that both molecules attenuated ethanol drinking in $\mathrm{Wt}$, but not in the NOP $(-/-)$ line. This finding is consistent with results obtained with NOP $\mathrm{KO}$ rats indicating that pharmacological blockade of NOP reproduces the same effects observed following genetic deletion of the receptor. Moreover, these data provide confirmation for a recent study showing that NOP 
antagonism attenuates the motivation for alcohol (RorickKehn et al, 2016). On the basis of current literature, there are two main observations that need to be reconciled with our results. First, in previous work, NOP $(-/-)$ mice, contrary to NOP $(-/-)$ rats, were characterized by enhanced sensitivity to the rewarding and psychoactive effects of drugs of abuse (Marquez et al, 2008, 2013; Sakoori and Murphy, 2009), as measured by higher CPP for morphine, alcohol, and cocaine, and a slightly enhanced locomotor sensitization following psychostimulants (Marquez et al, 2008, 2013; Rutten et al, 2011). Moreover, in CPP studies in rats it was shown that pharmacological blockade or genetic deletion of NOP facilitates the acquisition of preference for a morphinepaired compartment (Rutten et al, 2011). In contrast, other studies showed that behavioral sensitization to methamphetamine was lower in NOP $(-/-)$ mice (Sakoori and Murphy, 2008a) and most importantly, the same authors found that ethanol drinking was lower in NOP $(-/-)$ mice compared with Wt mice. This finding is in line with our results of NOP KO animals self-administering less ethanol compared with controls. In addition, although Wt mice exhibited enhanced methamphetamine- and ethanolinduced CPP after chronic administration of UFP-101, this effect was absent in NOP $(-/-)$ mice. Hence, although data in NOP $(-/-)$ mice are not unequivocal, this latter work suggests that also in mice, NOP receptor deletion may counteract the effects of chronic exposure to drugs of abuse. Clearly, the inconsistencies among data obtained from KO animals may be dependent on the different animal models and behavioral procedures used. Moreover, the heterogeneity of the dose chosen and duration of drug exposure (chronic vs acute) could be crucial for the experimental outcomes and makes it difficult to directly compare results from different studies. Nevertheless, these findings, together with data showing that pharmacological blockade of NOP attenuates alcohol self-administration and relapse to alcohol seeking, provide support to the possibility that inhibition of N/OFQ transmission may have beneficial effects on addiction (Rorick-Kehn et al, 2016).

A second set of data contrasting with our findings relates to the inhibition of drug abuse-related behaviors following activation of NOP receptors by agonists. For instance, it has been shown that activation of NOP receptors by N/OFQ or by selective synthetic agonists reduces alcohol self-administration, attenuates opioid- and cocaine-induced CPP, and prevents reinstatement behavior (Witkin et al, 2014; Zaveri, 2011). However, a recent study reported that NOP receptor activation did not affect cocaine CPP, nor did it affect reinstatement behavior elicited by cocaine priming or by administration of the pharmacological stressor yohimbine (Sartor et al, 2016). Most importantly, in a series of studies carried out in our laboratories, we have found that genetically selected msP rats, that are characterized by innate predisposition to excessive drinking, have an elevated expression of N/OFQ and NOP receptor transcripts in several brain areas (Economidou et al, 2008; Hansson et al, 2006). We also observed that N/OFQ signaling is heavily affected by chronic ethanol, as evidenced by the upregulation of NOP receptor transcript in the CeA and BNST, and of the N/OFQ transcript in the BNST, in rats with a history of ethanol dependence (Aujla et al, 2013). These findings provide a link between upregulation of the NOP system and increased propensity to excessive drinking and possibly transition to a later stage of addiction. This hypothesis is additionally supported by data showing that, in $\mathrm{msP}$ rats, ethanol intake was enhanced following acute administration of NOP agonists (Economidou et al, 2006a). Conversely, ethanol consumption was progressively decreased following repeated NOP agonist treatment and remained low for several days after treatment discontinuation (Ciccocioppo et al, 2014). This effect may be consistent with the hypothesis that NOP agonists attenuate alcohol drinking through mechanisms involving downregulation or desensitization of NOP receptors (Ciccocioppo et al, 2014). Indeed, multiple groups have demonstrated rapid and robust NOP receptor desensitization and internalization in vitro in response to either N/OFQ or synthetic NOP agonists (Corbani et al, 2004; Dautzenberg et al, 2001; Spampinato and Baiula, 2006). Moreover, electrophysiological studies revealed that following administration of N/OFQ, postsynaptic NOP receptors rapidly desensitize, whereas presynaptic receptors continue to function normally. Hence, complex reorganization of the activity of NOP-related neurocircuitry may also occur and may be responsible for the effects on alcohol (Pennock et al, 2012).

In conclusion, these results demonstrate that genetic deletion of NOP receptors confers resilience to abused psychoactive drugs. This effect appears to be specific as operant behavior reinforced by natural rewards (ie, saccharin) is not altered in NOP $(-/-)$. Pharmacological blockade of NOP receptors by selective antagonists specifically attenuated the motivation for alcohol in Wt but not in NOP $(-/-)$ rats. A novel NOP antagonist with a safe pharmacological profile is currently under investigation for depression in humans (Post et al, 2016). Substance use disorders may possibly represent an additional clinical indication for this compound.

The present work sheds new light on the role of the N/OFQ-NOP system in addiction and prompts a new intriguing hypothesis supporting a role for receptor antagonism as a treatment option for drug dependence.

\section{FUNDING AND DISCLOSURE}

This study was supported by grant NIH/NIAAA AA014351 (to FW). The authors declare no conflict of interest.

\section{ACKNOWLEDGMENTS}

We thank Rina Righi and Serena Stopponi for animal breeding and expert technical assistance.

\section{REFERENCES}

Aujla H, Cannarsa R, Romualdi P, Ciccocioppo R, Martin-Fardon R, Weiss F (2013). Modification of anxiety-like behaviors by nociceptin/orphanin FQ (N/OFQ) and time-dependent changes in N/OFQ-NOP gene expression following ethanol withdrawal. Addict Biol 18: 467-479.

Briant JA, Nielsen DA, Proudnikov D, Londono D, Ho A, Ott J et al (2010). Evidence for association of two variants of the nociceptin/ orphanin FQ receptor gene OPRL1 with vulnerability to develop opiate addiction in Caucasians. Psychiatr Genet 20: 65-72. 
Ciccocioppo R, Angeletti S, Panocka I, Massi M (2000a). Nociceptin/orphanin FQ and drugs of abuse. Peptides 21: 1071-1080.

Ciccocioppo R, Angeletti S, Sanna PP, Weiss F, Massi M (2000b). Effect of nociceptin/orphanin FQ on the rewarding properties of morphine. Eur J Pharmacol 404: 153-159.

Ciccocioppo R, Economidou D, Cippitelli A, Cucculelli M, Ubaldi M, Soverchia L et al (2006). Genetically selected Marchigian Sardinian alcohol-preferring $(\mathrm{msP})$ rats: an animal model to study the neurobiology of alcoholism. Addict Biol 11: 339-355.

Ciccocioppo R, Economidou D, Fedeli A, Angeletti S, Weiss F, Heilig M et al (2004). Attenuation of ethanol self-administration and of conditioned reinstatement of alcohol-seeking behaviour by the antiopioid peptide nociceptin/orphanin FQ in alcoholpreferring rats. Psychopharmacology 172: 170-178.

Ciccocioppo R, Stopponi S, Economidou D, Kuriyama M, Kinoshita H, Heilig M et al (2014). Chronic treatment with novel brain-penetrating selective NOP receptor agonist MT-7716 reduces alcohol drinking and seeking in the rat. Neuropsychopharmacology 39: 2601-2610.

Corbani M, Gonindard C, Meunier JC (2004). Ligand-regulated internalization of the opioid receptor-like 1: a confocal study. Endocrinology 145: 2876-2885.

Darland T, Heinricher MM, Grandy DK (1998). Orphanin FQ/nociceptin: a role in pain and analgesia, but so much more. Trends Neurosci 21: 215-221.

Dautzenberg FM, Wichmann J, Higelin J, Py-Lang G, Kratzeisen C, Malherbe $\mathrm{P}$ et al (2001). Pharmacological characterization of the novel nonpeptide orphanin FQ/nociceptin receptor agonist Ro 64-6198: rapid and reversible desensitization of the ORL1 receptor in vitro and lack of tolerance in vivo. J Pharmacol Exp Ther 298: 812-819.

de Guglielmo G, Martin-Fardon R, Teshima K, Ciccocioppo R, Weiss F (2015a). MT-7716, a potent NOP receptor agonist, preferentially reduces ethanol seeking and reinforcement in postdependent rats. Addict Biol 20: 643-651.

de Guglielmo G, Melis M, De Luca MA, Kallupi M, Li HW, Niswender $\mathrm{K}$ et al (2015b). PPARgamma activation attenuates opioid consumption and modulates mesolimbic dopamine transmission. Neuropsychopharmacology 40: 927-937.

Economidou D, Fedeli A, Fardon RM, Weiss F, Massi M, Ciccocioppo R (2006a). Effect of novel nociceptin/orphanin FQ-NOP receptor ligands on ethanol drinking in alcoholpreferring msP rats. Peptides 27: 3299-3306.

Economidou D, Hansson AC, Weiss F, Terasmaa A, Sommer WH, Cippitelli A et al (2008). Dysregulation of nociceptin/orphanin FQ activity in the amygdala is linked to excessive alcohol drinking in the rat. Biol Psychiatry 64: 211-218.

Economidou D, Mattioli L, Cifani C, Perfumi M, Massi M, Cuomo V et al (2006b). Effect of the cannabinoid CB1 receptor antagonist SR-141716A on ethanol self-administration and ethanol-seeking behaviour in rats. Psychopharmacology 183: 394-403.

Gavioli EC, Calo G (2013). Nociceptin/orphanin FQ receptor antagonists as innovative antidepressant drugs. Pharmacol Ther 140: $10-25$.

Hansson AC, Cippitelli A, Sommer WH, Fedeli A, Bjork K, Soverchia L et al (2006). Variation at the rat Crhr1 locus and sensitivity to relapse into alcohol seeking induced by environmental stress.

Proc Natl Acad Sci USA 103: 15236-15241.

Holanda VA, Medeiros IU, Asth L, Guerrini R, Calo G, Gavioli EC (2016). Antidepressant activity of nociceptin/orphanin FQ receptor antagonists in the mouse learned helplessness. Psychopharmacology 233: 2525-2532.

Homberg JR, Mul JD, de Wit E, Cuppen E (2009). Complete knockout of the nociceptin/orphanin FQ receptor in the rat does not induce compensatory changes in mu, delta and kappa opioid receptors. Neuroscience 163: 308-315.

Huang J, Young B, Pletcher MT, Heilig M, Wahlestedt C (2008). Association between the nociceptin receptor gene (OPRL1) single nucleotide polymorphisms and alcohol dependence. Addict Biol 13: $88-94$.

Jenck F, Wichmann J, Dautzenberg FM, Moreau JL, Ouagazzal AM, Martin JR et al (2000). A synthetic agonist at the orphanin FQ/ nociceptin receptor ORL1: anxiolytic profile in the rat. Proc Natl Acad Sci USA 97: 4938-4943.

Kallupi M, Cannella N, Economidou D, Ubaldi M, Ruggeri B, Weiss F et al (2010). Neuropeptide S facilitates cue-induced relapse to cocaine seeking through activation of the hypothalamic hypocretin system. Proc Natl Acad Sci USA 107: 19567-19572.

Kallupi M, Varodayan FP, Oleata CS, Correia D, Luu G, Roberto M (2014). Nociceptin/orphanin FQ decreases glutamate transmission and blocks ethanol-induced effects in the central amygdala of naive and ethanol-dependent rats. Neuropsychopharmacology 39: 1081-1092.

Kotlinska J, Wichmann J, Legowska A, Rolka K, Silberring J (2002). Orphanin FQ/nociceptin but not Ro 65-6570 inhibits the expression of cocaine-induced conditioned place preference. Behav Pharmacol 13: 229-235.

Kuzmin A, Kreek MJ, Bakalkin G, Liljequist S (2007). The nociceptin/orphanin FQ receptor agonist Ro 64-6198 reduces alcohol self-administration and prevents relapse-like alcohol drinking. Neuropsychopharmacology 32: 902-910.

Marquez P, Hamid A, Lutfy K (2013). The role of NOP receptors in psychomotor stimulation and locomotor sensitization induced by cocaine and amphetamine in mice. Eur J Pharmacol 707: 41-45.

Marquez P, Nguyen AT, Hamid A, Lutfy K (2008). The endogenous OFQ/N/ORL-1 receptor system regulates the rewarding effects of acute cocaine. Neuropharmacology 54: 564-568.

Meunier JC, Mollereau C, Toll L, Suaudeau C, Moisand C, Alvinerie P et al (1995). Isolation and structure of the endogenous agonist of opioid receptor-like ORL1 receptor. Nature 377: 532-535.

Mollereau C, Mouledous L (2000). Tissue distribution of the opioid receptor-like (ORL1) receptor. Peptides 21: 907-917.

Pennock RL, Dicken MS, Hentges ST (2012). Multiple inhibitory G-protein-coupled receptors resist acute desensitization in the presynaptic but not postsynaptic compartments of neurons. J Neurosci 32: 10192-10200.

Post A, Smart TS, Krikke-Workel J, Dawson GR, Harmer CJ, Browning $\mathrm{M}$ et al (2016). A selective nociceptin receptor antagonist to treat depression: evidence from preclinical and clinical studies. Neuropsychopharmacology 41: 1803-1812.

Reinscheid RK, Nothacker HP, Bourson A, Ardati A, Henningsen RA, Bunzow JR et al (1995). Orphanin FQ: a neuropeptide that activates an opioidlike $G$ protein-coupled receptor. Science 270: 792-794.

Richardson NR, Roberts DC (1996). Progressive ratio schedules in drug self-administration studies in rats: a method to evaluate reinforcing efficacy. J Neurosci Methods 66: 1-11.

Rizzi A, Gavioli EC, Marzola G, Spagnolo B, Zucchini S, Ciccocioppo R et al (2007). Pharmacological characterization of the nociceptin/orphanin FQ receptor antagonist SB-612111 [(-)-cis-1-methyl-7-[[4-(2,6-dichlorophenyl)piperidin-1-yl] methyl]-6,7,8,9-tetrah ydro-5H-benzocyclohepten-5-ol]: in vivo studies. J Pharmacol Exp Ther 321: 968-974.

Rizzi A, Molinari S, Marti M, Marzola G, Calo G (2011). Nociceptin/orphanin FQ receptor knockout rats: in vitro and in vivo studies. Neuropharmacology 60: 572-579.

Rorick-Kehn LM, Ciccocioppo R, Wong CJ, Witkin JM, Martinez-Grau MA, Stopponi S et al (2016). A novel, orally bioavailable nociceptin receptor antagonist, LY2940094, reduces ethanol self-administration and ethanol seeking in animal models. Alcohol Clin Exp Res 40: 945-954. 
Rutten K, De Vry J, Bruckmann W, Tzschentke TM (2010). Effects of the NOP receptor agonist Ro65-6570 on the acquisition of opiate- and psychostimulant-induced conditioned place preference in rats. Eur J Pharmacol 645: 119-126.

Rutten K, De Vry J, Bruckmann W, Tzschentke TM (2011). Pharmacological blockade or genetic knockout of the NOP receptor potentiates the rewarding effect of morphine in rats. Drug Alcohol Depend 114: 253-256.

Sakoori K, Murphy NP (2008a). Endogenous nociceptin (orphanin FQ) suppresses basal hedonic state and acute reward responses to methamphetamine and ethanol, but facilitates chronic responses. Neuropsychopharmacology 33: 877-891.

Sakoori K, Murphy NP (2008b). Expression of morphineconditioned place preference is more vulnerable than naloxoneconditioned place aversion to disruption by nociceptin in mice. Neurosci Lett 443: 108-112.

Sakoori K, Murphy NP (2009). Enhanced nicotine sensitivity in nociceptin/orphanin FQ receptor knockout mice. Neuropharmacology 56: 896-904.

Sartor GC, Powell SK, Wiedner HJ, Wahlestedt C, Brothers SP (2016). Nociceptin receptor activation does not alter acquisition, expression, extinction and reinstatement of conditioned cocaine preference in mice. Brain Res 1632: 34-41.

Semenova S, Markou A (2003). Cocaine-seeking behavior after extended cocaine-free periods in rats: role of conditioned stimuli. Psychopharmacology 168: 192-200.

Spagnolo B, Carra G, Fantin M, Fischetti C, Hebbes C, McDonald J et al (2007). Pharmacological characterization of the nociceptin/ orphanin FQ receptor antagonist SB-612111 [(-)-cis-1-methyl-7[[4-(2,6-dichlorophenyl)piperidin-1-yl]methyl]-6,7,8,9-tetrah ydro-5H-benzocyclohepten-5-ol]: in vitro studies. J Pharmacol Exp Ther 321: 961-967.
Spampinato S, Baiula M (2006). Agonist-regulated endocytosis and desensitization of the human nociceptin receptor. Neuroreport 17: 173-177.

Statnick MA, Chen Y, Ansonoff M, Witkin JM, Rorick-Kehn L, Suter TM et al (2016). A Novel nociceptin receptor antagonist LY2940094 inhibits excessive feeding behavior in rodents: a possible mechanism for the treatment of binge eating disorder. $J$ Pharmacol Exp Ther 356: 493-502.

Toledo MA, Pedregal C, Lafuente C, Diaz N, Martinez-Grau MA, Jimenez A et al (2014). Discovery of a novel series of orally active nociceptin/orphanin FQ (NOP) receptor antagonists based on a dihydrospiro(piperidine-4,7'-thieno[2,3-c]pyran) scaffold. J Med Chem 57: 3418-3429.

Walker JR, Spina M, Terenius L, Koob GF (1998). Nociceptin fails to affect heroin self-administration in the rat. Neuroreport 9: 2243-2247.

Witkin JM, Statnick MA, Rorick-Kehn LM, Pintar JE, Ansonoff M, Chen Y et al (2014). The biology of nociceptin/orphanin FQ (N/OFQ) related to obesity, stress, anxiety, mood, and drug dependence. Pharmacol Ther 141: 283-299.

Xuei X, Flury-Wetherill L, Almasy L, Bierut L, Tischfield J, Schuckit M et al (2008). Association analysis of genes encoding the nociceptin receptor (OPRL1) and its endogenous ligand (PNOC) with alcohol or illicit drug dependence. Addict Biol 13: 80-87.

Zaveri NT (2011). The nociceptin/orphanin FQ receptor (NOP) as a target for drug abuse medications. Curr Top Med Chem 11: 1151-1156.

Zhang H, Wang F, Kranzler HR, Zhao H, Gelernter J (2013). Profiling of childhood adversity-associated DNA methylation changes in alcoholic patients and healthy controls. PloS One 8: e65648.

Zhao RJ, Woo RS, Jeong MS, Shin BS, Kim DG, Kim KW (2003). Orphanin FQ/nociceptin blocks methamphetamine place preference in rats. Neuroreport 14: 2383-2385. 